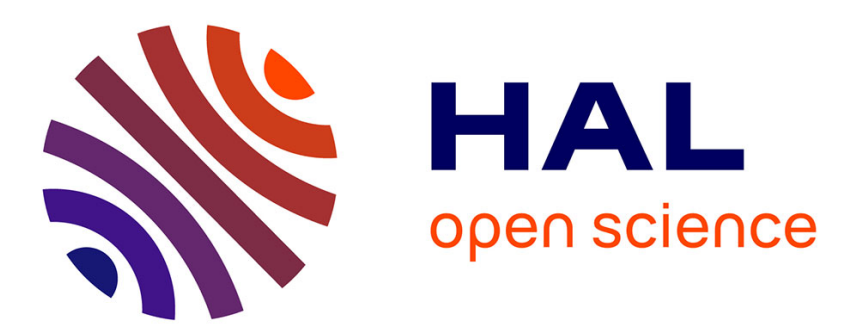

\title{
Genetic influences on adult BMI followed over 29 years and their effects on late life mobility: a study of twin sisters
}

Alfredo Ortega-Alonso, Sarianna Sipilä, Urho M Kujala, Jaakko Kaprio, Taina Rantanen

\section{To cite this version:}

Alfredo Ortega-Alonso, Sarianna Sipilä, Urho M Kujala, Jaakko Kaprio, Taina Rantanen. Genetic influences on adult BMI followed over 29 years and their effects on late life mobility: a study of twin sisters. Journal of Epidemiology and Community Health, 2009, 63 (8), pp.651-n/a. 10.1136/jech.2008.080622 . hal-00477872

\section{HAL Id: hal-00477872 \\ https://hal.science/hal-00477872}

Submitted on 30 Apr 2010

HAL is a multi-disciplinary open access archive for the deposit and dissemination of scientific research documents, whether they are published or not. The documents may come from teaching and research institutions in France or abroad, or from public or private research centers.
L'archive ouverte pluridisciplinaire HAL, est destinée au dépôt et à la diffusion de documents scientifiques de niveau recherche, publiés ou non, émanant des établissements d'enseignement et de recherche français ou étrangers, des laboratoires publics ou privés. 


\section{Genetic influences on adult BMI followed over 29 years and their}

\section{effects on late life mobility: a study of twin sisters}

Alfredo Ortega-Alonso, MSc. ${ }^{1}$ Sarianna Sipilä, PhD. ${ }^{1}$ Urho M. Kujala, PhD MD. ${ }^{1}$ Jaakko Kaprio, PhD MD. ${ }^{2,3}$ Taina Rantanen, PhD. ${ }^{1}$

${ }^{1}$ Department of Health Sciences, University of Jyväskylä, Jyväskylä, Finland

${ }^{2}$ Department of Public Health, University of Helsinki, Helsinki, Finland

${ }^{3}$ Department of Mental Health and Alcohol Research, National Public Health Institute, Helsinki, Finland

\section{Corresponding author:}

Alfredo Ortega-Alonso, Department of Health Sciences, University of Jyväskylä, PO Box 35 (Viveca), 40014, Jyväskylä, Finland, Phone: (+358) 142602153, Fax: (+358) 142604600, E-mail: alfredo.ortega@sport.jyu.fi

The Corresponding Author has the right to grant on behalf of all authors and does grant on behalf of all authors, an exclusive license (or non-exclusive for government employees) on a worldwide basis to the BMJ Publishing Group Ltd and its Licensees to permit this article (if accepted) to be published in JECH and any other BMJPGL products to exploit all subsidiary rights, as set out in our license.

Competing interests: there are no competing interests

\# Words in text: 3360

\# Tables: 3

\# Figures: 1

Keywords: longitudinal, genetics, obesity, mobility, adult women, 


\begin{abstract}
Background: The rise in body mass index (BMI) during adulthood increases the risk for metabolic disorders, functional limitations and disability in old age. This twin study examined prospectively whether genetic and environmental influences on women's BMI also account for mobility 29 years later.
\end{abstract}

Methods: The sample consisted of 103 monozygotic and 114 dizygotic pairs of twin sisters reared together. BMI was initially evaluated in year the 1975 , when the women were aged $42.6 \pm 3.4$ years, and was followed-up in 1981, 1990, 2001 and 2004. Mobility was evaluated using the standardized 6-minute walking test in 2001, when the women were aged 68.6 \pm 3.2 years, and followed-up 3 years later. We investigated how genetic and environmental influences on adult BMI accounted for mobility in old age using a genetic latent growth modeling approach

Results: During the follow-up period, BMI increased by 17\%. Midlife BMI was a significant predictor of mobility 29 years later. Genetic influences on BMI level and its rate-of-change accounted for $37 \%$ and $25 \%$ respectively, of the genetic influences on mobility later in life. The corresponding environmental influences on BMI level and its rate-of-change were $35 \%$ and $22 \%$.

Conclusion: Genes predisposing to higher BMI across middle age increase the risk for poorer mobility in old age. Identifying those genes could lead to interventions targeted at preventing obesity and mobility loss later in life. However, modification of environmental factors, e.g. exercise and nutrition remain the most feasible ways of influencing BMI and mobility across the life span. 


\section{Introduction}

Weight gain through midlife has become common nowadays in both men and women,[1] and increases the risk for functional limitations later in life.[2, 3] Earlier studies have suggested several pathways by which this may occur. For example, carrying excess body weight multiplies the mechanical stress on the lower limbs and may induce knee and hip osteoarthritis.[4] Increased body fat is related to a chain of metabolic disorders such as dyslipemia, atherogenesis, diabetes or hypertension, which in turn predict muscle weakness and mobility limitations.[5-8]

Interindividual differences in body mass index (BMI) within a population are determined by both genetic and environmental factors. It is estimated that $40-70 \%$ of BMI variability is due to genetic influences, depending on age, sex and ethnicity.[9, 10] It has been proposed that part of this genetic influence (20-35\%) derives from a mixed effect of major genes, while the remainder is the result of a complex additive polygenic component.[11]

Mobility in older age is also accounted for by genetic and environmental influences. Among older men, additive genetic influences explained $42 \%$ of individual differences in customary walking speed.[12] Among older women, previous reports using somewhat different approaches have identified additive genetic influences accounting for $11-56 \%$ of individual differences in maximal walking speed $[13,14]$ and $20-60 \%$ of walking endurance.[15]

The results from our earlier studies of female twins suggested that about $64 \%$ of the rate-of-change in women's BMI across 29 years was due to genetic influences, [16] which is comparable to the $64 \%$ heritability of rate-of-change among over 10.000 twins in a 15 years follow-up.[17] Further cross-sectional analyses showed that $65-80 \%$ of the association between adiposity and mobility in older age was due to genetic influences common to both phenotypes.[18] To recognize the actual role of the genetics of obesity on late-life health status, it is important to characterize individual changes in weight and BMI over longer periods of time, hence minimizing the effect of short-term fluctuations. In the present study, the factors underlying the evolution of BMI are examined 
prospectively, by hypothesizing that genetic influences on BMI level and its rate-of-change from midlife onwards over 29 years also account for the level of mobility at older ages.

\section{Methods}

\section{Participants}

The participants in this study represent a unique group of 217 twin pairs who consented to participate in the Finnish Twin Cohort Study (in years 1975, 1981, 1990) and later in the Finnish Twin Study on Aging - FITSA (in 2001 and 2004) [19]. A detail description of the selection procedures in the Finnish Twin Cohort is reported elsewhere.[20] The selection procedures in FITSA were as follows.

A subset of 414 twin pairs from the Finnish Twin Cohort Study was contacted in the year 2000. All of them were female twin sisters reared together and aged 63 to 76 years. To be included in the study, both sisters had to agree to take part. Reasons for non-participation were that one or both sisters were unwilling to take part (106 pairs), had poor health status (85 pairs) or had died since vital status was last updated for all cohort members (6 pairs). In the year 2001, 103 monozygotic (MZ) and 114 dizygotic (DZ) intact twin pairs took part in an assessment of health and functional capacity. Data on weight and height were gathered from all participating pairs, of whom $170 \mathrm{MZ}$ and $189 \mathrm{DZ}$ individuals also completed the 6-minute walking endurance test.

In 2004, an invitation to participate in a follow-up examination was sent to all the baseline participants. Eight individuals refused to participate due to poor health status, 7 individuals had died and 106 individuals consented to participate solely in an interview. Thus, the follow-up sample consisted of $149 \mathrm{MZ}$ and $164 \mathrm{DZ}$ individuals, including $70 \mathrm{MZ}$ and $75 \mathrm{DZ}$ complete pairs, who consented to participate in the laboratory measurements as well as the interview. At this 3-year follow-up, weight and height measurements were taken for all participants, of whom $103 \mathrm{MZ}$ and $110 \mathrm{DZ}$ individuals also completed the 6-minunte walking endurance test. 
All data available on BMI and walking endurance from each person was entered in the analyses. Participation number at every wave of data collection is shown in table 1. Seventy eight percent of the study sample had BMI data from 5 or 4 occasions, while $18 \%$ had data from 3 occasions and only less than $4 \%$ had data from 2 occasions or less. Concerning mobility, $58 \%$ of the sample had data on walking from the 2 occasions that they were collected, while $42 \%$ had data only from a single occasion.

\section{Measurements}

Data on the BMI of the FITSA participants was initially collected as part of the Finnish Twin Cohort study in the years 1975, 1981 and 1990. Participants' body height and weight were gathered using a standardized questionnaire. BMI was computed as weight $(\mathrm{kg})$ divided by height squared

$\left(\mathrm{m}^{2}\right)$. The validity and reliability of the questionnaire was controlled in a sub-sample of twin sisters $[21,22]$ by comparing self-reported weight and height with measures taken in a clinical examination after the questionnaire. The correlation between self-reported and measured BMI was 0.90, which suggested that the self-reported BMI had good reliability. A more detailed description of the measurement protocol used in the Finnish Twin Cohort study is given elsewhere.[23]

In the years 2001 and 2004, the participants undertook a clinical examination where body weight (to the nearest $0.1 \mathrm{~kg}$ ) and height (to the nearest $0.5 \mathrm{~cm}$ ) were measured in light indoor clothing without shoes using a calibrated beam-balance and a medical stadiometer, respectively. Body mass index was later computed using the aforementioned algorithm. Data on participants' BMI was thus available for the 5 waves of observations between 1975 and 2004.

Mobility was evaluated in the years 2001 and 2004 using a validated 6-minute walking test. The subjects were requested to walk back and forth along a $50 \mathrm{~m}$ indoor straight track for six minutes and to complete as many laps as possible. The standardized protocol and security conditions followed the American Thoracic Society Statement.[24] The distance covered by the end of the six minutes was recorded as the outcome. 


\section{Statistical procedures}

The normality of the data was tested by the Kolmogorov-Smirnov test, equality of means and variances by ANOVA and t-test for repeated measures using SPSS software. The relations between BMI at every data collection wave and mobility in 2001 and 2004 were analyzed by computing age- and baseline BMI- adjusted linear regression models for complex samples on STATA 8.0 software, which allows controlling for the clustering of observations from twin pairs.

Data on BMI was statistically transform using power transformation methods (power 1/3) to avoid high skewness at some of the follow-ups that may compromise more complex analyses. To obtain preliminary information on the within-pair resemblance in each phenotype, we computed intraclass correlation coefficients (ICCs) for MZ and DZ twins. The twin data were analyzed later using biometric methods.[25] It is assumed that the variance in each phenotype is a linear function of three different sources of influence: additive genetic influences (labelled as A), reflecting the sum of the additive allelic effects of many segregating genes, common environmental influences (C), reflecting the effects of environmental factors shared by twins in a pair, and specific environmental influences (E), reflecting environmental experiences and exposures unique to each person. MZ twins share $100 \%$ of their genes, and DZ twins share on average $50 \%$ of their segregating genes. The extent to which MZ twins are more similar to each other than DZ twins is taken as an indication of the importance of genetic influences. Environmental influences shared by siblings in a family are common to both types of twins and are expected to contribute equally to the similarity between the MZ and DZ pairs. Individual-specific environmental factors contribute only to differences within pairs. Biometric methods enable estimates of $\mathrm{A}, \mathrm{C}$ and $\mathrm{E}$ for different traits to be estimated from the information available on the twin and co-twin covariance structure and comparing observed and expected variance-covariance matrices. 
As a first step, a series of Cholesky decompositions were fitted to determine whether A, C and E definitively influenced BMI and mobility, and would thus have to be included in subsequent, more complex models. To estimate the extent to which genetic and environmental influences accounted for the stability and rate-of-change of BMI during the period from 1975 to 2004, a sequence of models were built and tested using the biometric growth model method proposed by Neale and MacArdle.[26] The biometric growth model technique estimates genetic and environmental influences arising from two possible latent sources: a Level or stable component throughout the study period and a Slope component representing the rate-of-linear-change across waves of observations. Level and Slope effects are considered general and they contribute to the variance at all the data collection waves. These two general components are allowed to covary. However, while the Level effects are considered stable at every wave, the Slope effects are differently loaded across waves. These loads must be specified in the model and may vary, depending on the rate-of-change of the given phenotype (e.g. linear, quadratic or cubic rate-of-change). In the present study a linear component of Slope was modelled as the normal change in BMI within an adult population normally follows a progressive linear trend.[27]

The latent growth models were adapted to the present data in the sense proposed by Mehta and West [28] to avoid biased estimates. Due to age differences in the sample, the individual's age was introduced as a definition variable. In addition, as the data collection waves were not evenly distributed over the 29-year follow-up, the loads from the Slope component in the model needed to be adjusted. Thus, while the loads from the Level component were fixed to 1, the respective loads from the Slope component were 0 (or no growth), 1, 2.5, 4.33 and 4.83. These values are expressed in 6-year time units for the known intervals of 6, 15, 25 and 29 years from wave 1 onwards. Residuals or wave-specific effects are allowed in growth modelling. Initially these residuals were modelled as deriving from genetic and environmental sources and thus they reflect variances at a 
given time not explained by longitudinal components. Due to the nature of the residuals, they are not allowed to covary across waves.

Finally, a new latent component was introduced in the initial growth modelling procedures, which accounted for the stable component (Level) of mobility in the last 3 years of the study period, using the information on mobility from waves 4 and 5 of the study. As a result, we built and tested a complex growth model with 7 phenotypes (5 waves of BMI and 2 waves of Mobility).

Models were fitted to the raw data with Mx software [29] by using maximum likelihood algorithms and treating unobserved data as missing-at-random.[30] This approach corrects the likelihood of the model for missing data and usually offers more accurate estimates of parameters than standard analyses in which pairs are deleted due to missing data.[31]

The significance of estimates and path coefficients were tested by removing them sequentially in different subsequent models. Their fit was compared against the fit of the unconstrained initial model in which higher number of possible paths of relations and estimates were present. This comparison was done by applying likelihood-ratio tests.[26] Likelihood-ratio tests are based on the deviance variation $(-2 \ln (\mathrm{L})$ and degrees of freedom) between an initial, unconstrained model and a candidate, hypothetical model. In the case where the likelihood of the hypothetical sub-model is statistically different $(\mathrm{p} \leq 0.05)$ from than of the initial model, then the fit of the sub-model is poorer and it may be rejected. Because likelihood-ratio tests tend to favor models with more estimated parameters, we supplemented the fitting process for the growth model with the Akaike's Information Criterion (AIC) [32] and the Schwartz's Bayesian Information Criterion (BIC).[33] The AIC disfavors models with more parameters and so balances model fit with model parsimony. Its use is recommended in large models where minor deviations may result in differences in likelihood-ratio.[34] Similarly, the BIC disfavors models with a larger number of estimated parameters, but it also takes into account sample size. Smaller AIC and BIC values indicate a better fit with the data. 


\section{Results}

Table 1 shows the characteristics of and values for the study sample at every measurement wave. Mean and variances of BMI and mobility did not differ by zygosity at any time. Mean BMI increased in the overall sample during the study period from 23.9 (95\%CI: 23.5-24.3) to 28.2 (95\%CI: $27.5-28.7) \mathrm{kg} / \mathrm{m}^{2}$, which represented a total average increment of 4.1 (95\%CI: $3.7-4.5$ ) $\mathrm{kg} / \mathrm{m}^{2}$ or $17 \%$ (95\%CI: $15.4-18.4 \%$ ) of the initial status. At baseline, only $4.4 \%$ of the sample had BMI over $30 \mathrm{~kg} / \mathrm{m}^{2}$, while at wave 4 the corresponding percentage had increased to $28.1 \%$ and at wave 5 to $31.4 \%$.

The average distance in the 6-minute walking tests were $525.4 \mathrm{~m}$ (95\%CI 517.8-533.1m) at wave 4 and $519.0 \mathrm{~m}(95 \% \mathrm{CI}: 508.8-529.3 \mathrm{~m})$ at wave 5. Age-adjusted linear regression analyses for complex samples (Table 2) showed that BMI and BMI rate-of-change across waves predicted latelife mobility level $(\mathrm{p}<0.001)$.

The analyses of the ICCs (table 1) showed that the MZ twins resembled each other more than did the DZ twins for both BMI and mobility, suggesting the presence of additive genetic influences. Preliminary Cholesky decompositions for BMI confirmed that an AE sub-model fitted the data better than the saturated model or other sub-models (table 3). Similarly, Cholesky decompositions for mobility at waves 4 and 5 confirmed that the AE models fitted the data well (results available from authors upon request). Consequently, subsequent longitudinal growth models including BMI and mobility variables were fitted on the bases of an AE parameterization.

The resulting best-fitting growth model (Figure 1) included additive genetic and specific environmental influences (AE) for adult BMI Level (A=60\%), BMI Slope (A=64\%), and Mobility Level at older age $(\mathrm{A}=63 \%)$. There were shared genetic and environmental influences between BMI Level and Slope (genetic correlation: $r_{\mathrm{g}}=-0.24$; environmental correlation: $r_{\mathrm{e}}=0.40$ ), between BMI Level and Mobility Level $\left(\mathrm{r}_{\mathrm{g}}=-0.37, \mathrm{r}_{\mathrm{e}}=-0.35\right)$, and between BMI Slope and Mobility Level $\left(\mathrm{r}_{\mathrm{g}}=-\right.$ $\left.0.22, \mathrm{r}_{\mathrm{e}}=-0.35\right)$ 
The heritability of BMI (or overall genetic influence on the trait) showed a consistent increasing trend, from $54 \%$ at wave 1 to $72 \%$ at wave 5 . Similarly, the overall heritability of mobility increased from $44 \%$ at wave 4 to $64 \%$ at wave 5. Finally, results also indicated the presence of environmental factors exclusive to each occasion, which explained 4 to $13 \%$ of the total variance at every wave.

\section{Discussion.}

The main result in the present study was that genetic influences underlying adult BMI and longitudinal changes in it had a moderate influence on late life mobility. Until now the association between obesity and mobility has been predominantly attributed to environmental factors such as physical activity or diet.[35, 36] However, these results provide novel understanding by showing that longitudinal genetic influences on obesity have also further impact on the late-life level of mobility.

The present study identified two different subsets of genetic effects on BMI: a subset of genes with stable effects on BMI across adult life (named here as BMI Level), along with another subset predominantly influencing the rate-of-change in BMI (or BMI Slope). These two subsets showed a positive genetic correlation of 0.40 , indicating that a share of the genes influencing higher BMI on a given occasion in part underlay the increase in BMI with age. This finding of two subsets of genes with possible shared effects is in line with earlier investigations among different twin samples.[37] For example, recent analyses of 15 years of data on BMI from the entire Finnish twin cohort showed some proportions of shared and specific genetic influences in BMI level and rate-ofchange.[17] This is supported as well by several observations at the molecular level. For instance, while the Pro1019Pro Lepr polymorphism in particular associated with both high adiposity and longitudinal gains in BMI,[38] there are some studies proposing additional genes (e.g. APO-E gene, the uncoupling protein 1 gene and the B3-adrenergic receptor gene polymorphisms) as specific 
regulators of longitudinal increments in adult body weight.[39-41] Yet, these specific genes have not been widely replicated as predictors of long-term weight gain.

In our study, both subsets of genetic effects on BMI (Level and Slope) had a negative correlation with mobility Level later in life (-0.37 and -0.25 , respectively). This indicates that genes predisposing to higher BMI across middle age account for poorer mobility in older age. Although the biological mechanisms are uncertain, there are some suggestive data on possible paths. Given that skeletal muscle is the primary site for glucose and triglyceride utilization,[42, 43] age-related muscle loss may contribute to peripheral insulin resistance, dyslipidemia and increased adiposity.[44] It has been suggested that a gradual impairment of the genetic regulation of cytokine protein expression with age may play a central role in these processes. For example, the genetic over-expression of TNF- $\alpha$ in muscle cells suppresses the expression of the lipoprotein lipase enzyme, increases body fat storage, and at the same time induces muscle loss and stimulates cell death.[44]

However, these genes are likely to work in interaction not only with each other [45] but also with short and long-term environmental influences and body stressors, such as physical activity and diet. For instance, resistance training and calorie restriction decrease muscle TNF- $\alpha$ expression, [44, 46] which may also coordinate the activation of other metabolic processes. Thus, this shared genetic mechanism underlying long-term changes in BMI and late life mobility would rely to a certain extent upon an interaction with environmental influences. Gene-exercise/diet interaction may regulate several metabolic processes and improve mobility by changing the expression of different genes and modulating muscle cells sensitivity to key proteins.[47, 48] As a result, although the genetic mechanisms involved in muscle cell metabolism might have a strong influence on the process of fat storage and physical functioning, environmental prompts such as physical activity and diet could determine the final phenotypic expression. Sustained overnutrition and physical inactivity over time will definitively contribute to manifest chronic diseases such as obesity and 
disability. Several twin studies have suggested that sedentary persons with genetic susceptibility to obesity are more prone to have larger BMI and waist circumference than those without genetic susceptibility.[49, 50] Waller and colleagues recently reported that in a sample of MZ twin pairs discordant for leisure-time physical activity during a 30-year period [51] persistent participation in leisure-time physical activity across adulthood was associated with decreased rate of weight gain and with a smaller waist circumference to a clinically significant extent, even after controlling for genetic predisposition. Thus, it seems that long-term commitments to exercising or healthy eating may prevent full realization of an individual's genetic predisposition to obesity [52] and so delay the onset of mobility disability. Nevertheless, observational and interventional studies as well as the clinical experience have already acknowledged the difficulties to maintain behaviourally mediated weight loss in the long-term, e.g., through dieting or increased amounts of daily physical activity.[53-55]

Among the advantages of this study are the use of population-based data and the relatively long follow-up. Moreover, mobility in old age was assessed using standardized measures of physical performance. We nevertheless acknowledge that we used self-report data on weight and height in the first three waves of this longitudinal design. Studies using self-reported weight and height have noticed a so-called "flat curve effect", with heavier persons tending to report values somewhat regressed toward the population average.[56] Therefore, the likelihood of reporting bias needs to be considered. However, the self-reported data on weight and height used here showed good reliability and accuracy when compared to the measured data.[21, 22] In addition, our model included estimates for specific environmental influences at each wave, which also captures potential measurement errors. Thus the estimates for the genetic influences on BMI are in turn adjusted for the potential effects caused by the difference between the first three and the last two waves in the method of assessing BMI. Genetic and environmental variances increased consistently across waves, regardless how the phenotype was measured. This makes it unlikely that the observed 
increment in heritability during the follow-up period could be entirely explained by differences in the accuracy of self-reported versus measured weight and height. Nonetheless, further replication studies are still needed.

Our analyses focused on estimating the influences underlying a linear rate-of-change in BMI. Therefore, populations or age groups, such as children, where BMI may well follow other trends (e.g. quadratic, exponential or logarithmic) are likely to show a different result. In our data, the observed increment in BMI was mostly due to weight gains in the study sample. However, a mean decrease of $3.6 \mathrm{~cm}$ in height over 29 years was also detected. Our study was limited to women without severe disability and therefore the results may not be directly generalizable to men and to people with poorer health. Finally, the sample showed some fluctuations in size across the data collection waves. Normally, this is a limiting issue of the genetic analyses, particularly in moderately sized twin samples, and it may potentially restrict the statistical power to detect and differentiate between additive genetic (A) and common environmental (C) influences. However, the estimates presented for genetic influences on BMI level and BMI rate-of-change are in line with those presented from analyses done utilizing the entire Finnish Twin cohort (utilizing data from more than 10.000 persons).[17] The fact that we did not find C on BMI seems also to agree with reports from other groups involving several thousands of twin pairs. In addition, power-transformed data on BMI was entered into the statistical modelling, which initially may help to ameliorate the sample-size effect and improve analytical power.[57] Despite the moderate size of our sample of women, fluctuations on the BMI data were relatively small (as $78 \%$ of the participants had data on BMI from 4 or more occasions) and seemed to be inconsequential for the results obtained. Considering the good fit of the models and the narrow confidence intervals of the estimates, the data do not appear to be power-limited to detect either genetic or environmental influences, although further replication analyses may be of help. 
In conclusion, genes predisposing to higher BMI and weight gain from midlife onwards also account for poorer mobility in old age. Identifying specific genes involved in human metabolism and weight gain could lead to interventions targeted at preventing obesity and mobility loss later in life. However, for the present, modification of environmental factors, such as exercise and nutrition remain the most feasible ways of influencing BMI and mobility across the life span.

\section{Acknowledgments}

This study was supported by the Finnish Ministry of Education, the University of Jyväskylä, the

Juho Vainio Foundation, the Academy of Finland - Centre of Excellence in Complex Disease Genetics and the European Union through the GENOMEUTWIN project (EU FP5 QLG2-CT-200201254). 


\section{What is already known on this subject?}

Epidemiological data indicates that body mass index (BMI) tend to increase during adulthood, which increases the risk for functional limitations and disability in old age. Until now, the mechanism underlying this between obesity measures and mobility is poorly understood and longitudinal data on a possible shared genetic background is very limited.

\section{What does this study add?}

This study showed that there are shared genetic influences of BMI and gain in BMI with mobility level in old age. Importantly, genes predisposing to higher BMI across middle age increase the risk for poorer mobility in old age. 


\section{References}

1 Flegal K. Obesity. In: Goldman MB, Hatch MC, eds. Women and health. San Diego, CA: Academic Press 2000:830-8.

2 Ferraro KF, Su YP, Gretebeck RJ, et al. Body mass index and disability in adulthood: a 20year panel study. Am J Public Health 2002;92:834-40.

3 Hubert HB, Bloch DA, Fries JF. Risk factors for physical disability in an aging cohort: the NHANES I Epidemiologic Followup Study. J Rheumatol 1993;20:480-8.

4 Hart DJ, Spector TD. The relationship of obesity, fat distribution and osteoarthritis in women in the general population: the Chingford Study. J Rheumatol 1993;20:331-5.

5 Stevens J, Gautman SP, Keil JE. Body mass index and fat patterning as correlates of lipids and hypertension in an elderly, biracial population. J Gerontol 1993;48:M249-54.

6 Kuo HK, Jones RN, Milberg WP, et al. Effect of blood pressure and diabetes mellitus on cognitive and physical functions in older adults: a longitudinal analysis of the advanced cognitive training for independent and vital elderly cohort. J Am Geriatr Soc 2005;53:1154-61.

7 Bruce DG, Davis WA, Davis TM. Longitudinal predictors of reduced mobility and physical disability in patients with type 2 diabetes: the Fremantle Diabetes Study. Diabetes Care

2005;28:2441-7.

8 Gregg EW, Sorlie P, Paulose-Ram R, et al. Prevalence of lower-extremity disease in the US adult population $>=40$ years of age with and without diabetes: 1999-2000 national health and nutrition examination survey. Diabetes Care 2004;27:1591-7.

9 Jacobson KC, Rowe DC. Genetic and shared environmental influences on adolescent BMI: interactions with race and sex. Behav Genet 1998;28:265-78.

10 Comuzzie AG, Allison DB. The search for human obesity genes. Science 1998;280:1374-7. 11 Moll PP, Burns TL, Lauer RM. The genetic and environmental sources of body mass index variability: the Muscatine Ponderosity Family Study. Am J Hum Genet 1991;49:1243-55.

12 Carmelli D, Kelly-Hayes M, Wolf PA, et al. The contribution of genetic influences to measures of lower-extremity function in older male twins. J Gerontol A Biol Sci Med Sci 2000;55:B49-53.

13 Leinonen R, Kaprio J, Jylha M, et al. Genetic influences underlying self-rated health in older female twins. J Am Geriatr Soc 2005;53:1002-7.

14 Pajala S, Era P, Koskenvuo M, et al. Contribution of genetic and environmental factors to individual differences in maximal walking speed with and without second task in older women. $J$ Gerontol A Biol Sci Med Sci 2005;60:1299-303.

15 Ortega-Alonso A, Pedersen NL, Kujala UM, et al. A twin study on the heritability of walking ability among older women. J Gerontol A Biol Sci Med Sci 2006;61:1082-5.

16 Ortega-Alonso A, Sipila S, Kujala U, et al. Genetic influences on change in BMI from middle to old age: a 29-year follow-up study of twin sisters. Behav Genet 2008 [Epub ahead of print].

17 Hjelmborg JV, Fagnani C, Silventoinen K, et al. Genetic Influences on Growth Traits of BMI: A Longitudinal Study of Adult Twins. Obesity (Silver Spring) 2008.

18 Ortega-Alonso A, Sipila S, Kujala UM, et al. Body fat and mobility are explained by common genetic and environmental influences in older women. Obesity (Silver Spring) 2008;16:1616-21.

19 Pajala S, Era P, Koskenvuo M, et al. Contribution of genetic and environmental effects to postural balance in older female twins. J Appl Physiol 2004;96:308-15.

20 Kaprio J, Koskenvuo M. Genetic and environmental factors in complex diseases: the older Finnish Twin Cohort. Twin Res 2002;5:358-65.

21 Korkeila M, Kaprio J, Rissanen A, et al. Predictors of major weight gain in adult Finns: stress, life satisfaction and personality traits. Int J Obes Relat Metab Disord 1998;22:949-57. 
22 Silventoinen K, Kaprio J, Lahelma E, et al. Relative effect of genetic and environmental factors on body height: differences across birth cohorts among Finnish men and women. Am J

Public Health 2000;90:627-30.

23 Silventoinen K, Sarlio-Lahteenkorva S, Koskenvuo M, et al. Effect of environmental and genetic factors on education-associated disparities in weight and weight gain: a study of Finnish adult twins. Am J Clin Nutr 2004;80:815-22.

24 ATS statement: guidelines for the six-minute walk test. Am J Respir Crit Care Med 2002;166:111-7.

25 Neale MC, Cardon LR. Methodology for genetic studies of twins and families. Dordrecht, The Netherlands: Kluwer Academic 1992.

26 Neale MC, McArdle JJ. Structured latent growth curves for twin data. Twin Res 2000;3:165-

77.

27 Strug L, Sun L, Corey M. The genetics of cross-sectional and longitudinal body mass index. BMC Genet 2003;4 Suppl 1:S14.

28 Mehta PD, West SG. Putting the individual back into individual growth curves. Psychol Methods 2000;5:23-43.

29 Neale MC. Mx: Statistical Modeling (6th ed.). Richmond, VA: Department of Psychiatry. Medical College of Virginia, Virginia Commonwealth University 2004.

$30 \quad$ Little RJA, Rubin DB. Statistical analysis with missing data. New York: Wiley 1987.

31 Greenland S, Finkle WD. A critical look at methods for handling missing covariates in epidemiologic regression analyses. Am J Epidemiol 1995;142:1255-64.

$32 \quad$ Akaike H. Factor analysis and AIC. Psychometrika 1987.

33 Schwartz G. Estimating the dimension of a model. Annals of Statistics 1978;6:461-4.

34 Christensen K, Frederiksen H, Vaupel JW, et al. Age trajectories of genetic variance in physical functioning: a longitudinal study of Danish twins aged 70 years and older. Behav Genet 2003;33:125-36.

35 Schroll M. Aging, food patterns and disability. Forum Nutr 2003;56:256-8.

36 Morgan K, Armstrong GK, Huppert FA, et al. Healthy ageing in urban and rural Britain: a comparison of exercise and diet. Age Ageing 2000;29:341-8.

37 Austin MA, Friedlander Y, Newman B, et al. Genetic influences on changes in body mass index: a longitudinal analysis of women twins. Obesity research 1997;5:326-31.

38 de Silva AM, Walder KR, Boyko EJ, et al. Genetic variation and obesity in Australian women: a prospective study. Obesity research 2001;9:733-40.

39 Gueguen R, Visvikis S, Steinmetz J, et al. An analysis of genotype effects and their interactions by using the apolipoprotein E polymorphism and longitudinal data. Am J Hum Genet 1989;45:793-802.

40 Sivenius K, Valve R, Lindi V, et al. Synergistic effect of polymorphisms in uncoupling protein 1 and beta3-adrenergic receptor genes on long-term body weight change in Finnish type 2 diabetic and non-diabetic control subjects. Int J Obes Relat Metab Disord 2000;24:514-9.

41 Clement K, Vaisse C, Manning BS, et al. Genetic variation in the beta 3-adrenergic receptor and an increased capacity to gain weight in patients with morbid obesity. $N$ Engl J Med 1995;333:352-4.

42 Lithell H, Lindgarde F, Hellsing K, et al. Body weight, skeletal muscle morphology, and enzyme activities in relation to fasting serum insulin concentration and glucose tolerance in 48year-old men. Diabetes 1981;30:19-25.

43 Dinneen S, Gerich J, Rizza R. Carbohydrate metabolism in non-insulin-dependent diabetes mellitus. N Engl J Med 1992;327:707-13.

44 Greiwe JS, Cheng B, Rubin DC, et al. Resistance exercise decreases skeletal muscle tumor necrosis factor alpha in frail elderly humans. Faseb J 2001;15:475-82. 
45 Warden $\mathrm{CH}$, Yi N, Fisler J. Epistasis among genes is a universal phenomenon in obesity: evidence from rodent models. Nutrition 2004;20:74-7.

46 Phillips T, Leeuwenburgh C. Muscle fiber specific apoptosis and TNF-alpha signaling in sarcopenia are attenuated by life-long calorie restriction. Faseb J 2005;19:668-70.

47 Ozcelik O, Celik H, Ayar A, et al. Investigation of the influence of training status on the relationship between the acute exercise and serum leptin levels in obese females. Neuro Endocrinol Lett 2004;25:381-5.

48 Tuomilehto J, Lindstrom J, Eriksson JG, et al. Prevention of type 2 diabetes mellitus by changes in lifestyle among subjects with impaired glucose tolerance. N Engl J Med 2001;344:134350 .

49 Heitmann BL, Kaprio J, Harris JR, et al. Are genetic determinants of weight gain modified by leisure-time physical activity? A prospective study of Finnish twins. Am J Clin Nutr 1997;66:672-8.

50 Karnehed N, Tynelius P, Heitmann BL, et al. Physical activity, diet and gene-environment interactions in relation to body mass index and waist circumference: the Swedish young male twins study. Public Health Nutr 2006;9:851-8.

51 Waller K, Kaprio J, Kujala UM. Associations between long-term physical activity, waist circumference and weight gain: a 30-year longitudinal twin study. Int J Obes (Lond) 2008;32:35361.

52 Hewitt J. The genetics of obesity: what have genetic studies told us about the environment. Behavior genetics 1997;27:353-8.

53 Kramer FM, Jeffery RW, Forster JL, et al. Long-term follow-up of behavioral treatment for obesity: patterns of weight regain among men and women. Int J Obes 1989;13:123-36.

54 Sarlio-Lahteenkorva S, Rissanen A, Kaprio J. A descriptive study of weight loss maintenance: 6 and 15 year follow-up of initially overweight adults. Int J Obes Relat Metab Disord 2000;24:116-25.

55 Schmitz MK, Jeffery RW. Public health interventions for the prevention and treatment of obesity. Med Clin North Am 2000;84:491-512, viii.

56 Kuskowska-Wolk A, Karlsson P, Stolt M, et al. The predictive validity of body mass index based on self-reported weight and height. Int J Obes 1989;13:441-53.

57 Chen WW, Deo RS. Power transformation to induce normality and their applications. $J R$ Statist Soc B 2004;66:117-30. 


\section{Tables and Figures}

Table 1: Subjects' characteristics and walking tests results (overall results and by zygosity) at every wave of measurements. Means, 95\% confidence intervals (95\% CI) and pairwise correlations (ICC) are also shown.

\begin{tabular}{|c|c|c|c|c|c|c|c|c|c|c|c|c|c|c|c|}
\hline \multirow[b]{2}{*}{ Variable } & \multicolumn{3}{|c|}{ WAVE 1: year 1975} & \multicolumn{3}{|c|}{ WAVE 2: year 1981} & \multicolumn{3}{|c|}{ WAVE 3: year 1990} & \multicolumn{3}{|c|}{ WAVE 4: year 2001} & \multicolumn{3}{|c|}{ WAVE 5: year 2004} \\
\hline & $\mathrm{N}$ * & $\begin{array}{c}\text { Mean } \\
(95 \% \text { CI })\end{array}$ & $\begin{array}{c}\text { ICC } \\
(95 \% \text { CI }) \\
\end{array}$ & $\mathbf{N}$ * & $\begin{array}{c}\text { Mean } \\
(95 \% \text { CI) }\end{array}$ & $\begin{array}{c}\text { ICC } \\
(95 \% \mathrm{CI}) \\
\end{array}$ & $\mathrm{N} *$ & $\begin{array}{c}\text { Mean } \\
(\mathbf{9 5 \%} \text { CI) }\end{array}$ & $\begin{array}{c}\text { ICC } \\
(95 \% \mathrm{CI}) \\
\end{array}$ & $\mathbf{N} *$ & $\begin{array}{c}\text { Mean } \\
(\mathbf{9 5 \%} \text { CI) }\end{array}$ & $\begin{array}{c}\text { ICC } \\
(95 \% \mathrm{CI}) \\
\end{array}$ & $\mathbf{N} *$ & $\begin{array}{c}\text { Mean } \\
(\mathbf{9 5 \%} \text { CI }) \\
\end{array}$ & $\begin{array}{c}\text { ICC } \\
(95 \% \mathrm{CI}) \\
\end{array}$ \\
\hline Age (years) & $414 / 200$ & $\begin{array}{c}42.6 \\
(42.3-42.9)\end{array}$ & & $396 / 190$ & $\begin{array}{c}48.6 \\
(48.3-49.0)\end{array}$ & & $254 / 118$ & $\begin{array}{c}55.7 \\
(55.4-56.0)\end{array}$ & & $434 / 217$ & $\begin{array}{c}68.6 \\
(68.3-69.0)\end{array}$ & & $313 / 145$ & $\begin{array}{c}71.1 \\
(69.7-71.4)\end{array}$ & \\
\hline - MZ twins & 193/92 & $\begin{array}{c}42.3 \\
(41.8-42.8)\end{array}$ & $\begin{array}{c}1.00 \\
(--)\end{array}$ & 190/89 & $\begin{array}{c}48.4 \\
(47.8-48.9)\end{array}$ & $\begin{array}{c}1.00 \\
(--)\end{array}$ & $120 / 56$ & $\begin{array}{c}55.3 \\
(54.9-55.8)\end{array}$ & $\begin{array}{c}1.00 \\
(--)\end{array}$ & $206 / 103$ & $\begin{array}{c}68.3 \\
(67.8-68.9)\end{array}$ & $\begin{array}{l}1.00 \\
(--)\end{array}$ & $149 / 70$ & $\begin{array}{c}70.5 \\
(69.9-71.1)\end{array}$ & $\begin{array}{l}1.00 \\
(--)\end{array}$ \\
\hline - DZ twins & $221 / 108$ & $\begin{array}{c}42.9 \\
(42.5-43.3)\end{array}$ & $\begin{array}{c}1.00 \\
(--)\end{array}$ & $206 / 101$ & $\begin{array}{c}48.9 \\
(48.4-49.3)\end{array}$ & $\begin{array}{l}1.00 \\
(--)\end{array}$ & $134 / 62$ & $\begin{array}{c}56.0 \\
(55.7-56.3)\end{array}$ & $\begin{array}{l}1.00 \\
(--)\end{array}$ & $228 / 114$ & $\begin{array}{c}68.9 \\
(68.3-69.0)\end{array}$ & $\begin{array}{c}1.00 \\
(--)\end{array}$ & $164 / 75$ & $\begin{array}{c}71.6 \\
(71.1-72.0)\end{array}$ & $\begin{array}{l}1.00 \\
(--)\end{array}$ \\
\hline Weight (kg) & $414 / 200$ & $\begin{array}{c}62.2 \\
(61.8-63.5)\end{array}$ & & $396 / 190$ & $\begin{array}{c}64.2 \\
(63.3-65.1)\end{array}$ & & $254 / 118$ & $\begin{array}{c}66.9 \\
(65.6-68.3)\end{array}$ & & $434 / 217$ & $\begin{array}{c}70.1 \\
(68.9-71.2)\end{array}$ & & $313 / 145$ & $\begin{array}{c}70.0 \\
(67.9-71.0)\end{array}$ & \\
\hline - MZ twins & 193/92 & $\begin{array}{c}62.2 \\
(61.0-63.3)\end{array}$ & $\begin{array}{c}0.63 \\
(0.49-0.74)\end{array}$ & $190 / 89$ & $\begin{array}{c}63.8 \\
(62.5-65.1)\end{array}$ & $\begin{array}{c}0.57 \\
(0.41-0.70)\end{array}$ & $120 / 56$ & $\begin{array}{c}66.3 \\
(64.4-68.2)\end{array}$ & $\begin{array}{c}0.91 \\
(0.85-0.94)\end{array}$ & $206 / 103$ & $\begin{array}{c}69.6 \\
(68.0-71.2)\end{array}$ & $\begin{array}{c}0.65 \\
(0.52-0.75)\end{array}$ & $149 / 70$ & $\begin{array}{c}69.0 \\
(66.2-70.9)\end{array}$ & $\begin{array}{c}0.70 \\
(0.56-0.80)\end{array}$ \\
\hline - DZ twins & $221 / 108$ & $\begin{array}{c}63.0 \\
(62.0-64.2) \\
\end{array}$ & $\begin{array}{c}0.32 \\
(0.14-0.48) \\
\end{array}$ & 206/101 & $\begin{array}{c}64.6 \\
(63.3-65.9) \\
\end{array}$ & $\begin{array}{c}0.30 \\
(0.12-0.47) \\
\end{array}$ & $134 / 62$ & $\begin{array}{c}67.5 \\
(65.6-69.4) \\
\end{array}$ & $\begin{array}{c}0.43 \\
(0.20-0.61) \\
\end{array}$ & $228 / 114$ & $\begin{array}{c}70.6 \\
(69.0-72.2) \\
\end{array}$ & $\begin{array}{c}0.41 \\
(0.25-0.55) \\
\end{array}$ & $164 / 75$ & $\begin{array}{c}70.4 \\
(68.4-72.4) \\
\end{array}$ & $\begin{array}{c}0.42 \\
(0.22-0.60) \\
\end{array}$ \\
\hline Height (m) & $414 / 200$ & $\begin{array}{c}1.61 \\
(1.60-1.62)\end{array}$ & & $396 / 190$ & $\begin{array}{c}1.61 \\
(1.60-1.62)\end{array}$ & & $254 / 118$ & $\begin{array}{c}1.60 \\
(1.60-1.62)\end{array}$ & & $434 / 217$ & $\begin{array}{c}1.58 \\
(1.57-1.59)\end{array}$ & & $313 / 145$ & $\begin{array}{c}1.57 \\
(1.57-1.58)\end{array}$ & \\
\hline - MZ twins & 193/92 & $\begin{array}{c}1.61 \\
(1.60-1.62)\end{array}$ & $\begin{array}{c}0.92 \\
(0.88-0.95)\end{array}$ & 190/89 & $\begin{array}{c}1.61 \\
(1.60-1.61)\end{array}$ & $\begin{array}{c}0.88 \\
(0.82-0.91)\end{array}$ & $120 / 56$ & $\begin{array}{c}1.60 \\
(1.60-1.61)\end{array}$ & $\begin{array}{c}0.74 \\
(0.59-0.84)\end{array}$ & $206 / 103$ & $\begin{array}{c}1.58 \\
(1.57-1.59)\end{array}$ & $\begin{array}{c}0.94 \\
(0.92-0.96)\end{array}$ & $149 / 70$ & $\begin{array}{c}1.57 \\
(1.56-1.58)\end{array}$ & $\begin{array}{c}0.94 \\
(0.91-0.97)\end{array}$ \\
\hline - DZ twins & $221 / 108$ & $\begin{array}{c}1.62 \\
(1.61-1.62) \\
\end{array}$ & $\begin{array}{c}0.50 \\
(0.34-0.63) \\
\end{array}$ & 206/101 & $\begin{array}{c}1.62 \\
(1.61-1.62) \\
\end{array}$ & $\begin{array}{c}0.48 \\
(0.31-0.62) \\
\end{array}$ & $134 / 62$ & $\begin{array}{c}1.61 \\
(1.60-1.62)\end{array}$ & $\begin{array}{c}0.40 \\
(0.17-0.59)\end{array}$ & $228 / 114$ & $\begin{array}{c}1.59 \\
(1.58-1.60)\end{array}$ & $\begin{array}{c}0.56 \\
(0.41-0.67)\end{array}$ & $164 / 75$ & $\begin{array}{c}1.58 \\
(1.57-1.59)\end{array}$ & $\begin{array}{c}0.53 \\
(0.34-0.67)\end{array}$ \\
\hline BMI $\left(\mathrm{kg} / \mathrm{m}^{2}\right)$ & $414 / 200$ & $\begin{array}{c}23.9 \\
(23.5-24.3)\end{array}$ & & $396 / 190$ & $\begin{array}{c}24.6 \\
(24.3-26.2)\end{array}$ & & $254 / 118$ & $\begin{array}{c}25.7 \\
(25.2-26.2)\end{array}$ & & $434 / 217$ & $\begin{array}{c}28.0 \\
(27.5-28.4)\end{array}$ & & $313 / 145$ & $\begin{array}{c}28.2 \\
(27.5-28.7)\end{array}$ & \\
\hline - MZ twins & $193 / 92$ & $\begin{array}{c}23.9 \\
(23.5-24.4)\end{array}$ & $\begin{array}{c}0.57 \\
(0.40-0.68)\end{array}$ & $190 / 89$ & $\begin{array}{c}24.6 \\
(24.1-25.0)\end{array}$ & $\begin{array}{c}0.59 \\
(0.43-0.71)\end{array}$ & $120 / 56$ & $\begin{array}{c}25.4 \\
(24.7-26.1)\end{array}$ & $\begin{array}{c}0.74 \\
(0.56-0.84)\end{array}$ & $206 / 103$ & $\begin{array}{c}28.0 \\
(27.3-28.7)\end{array}$ & $\begin{array}{c}0.62 \\
(0.48-0.72)\end{array}$ & $149 / 70$ & $\begin{array}{c}28.0 \\
(27.1-28.8)\end{array}$ & $\begin{array}{c}0.74 \\
(0.61-0.83)\end{array}$ \\
\hline - DZ twins & $221 / 108$ & $\begin{array}{c}24.1 \\
(23.7-24.3)\end{array}$ & $\begin{array}{c}0.29 \\
(0.11-0.46)\end{array}$ & 206/101 & $\begin{array}{c}24.7 \\
(24.2-25.2)\end{array}$ & $\begin{array}{c}0.29 \\
(0.10-0.46)\end{array}$ & $134 / 62$ & $\begin{array}{c}25.9 \\
(25.2-26.6)\end{array}$ & $\begin{array}{c}0.39 \\
(0.15-0.58)\end{array}$ & $228 / 114$ & $\begin{array}{c}28.0 \\
(27.3-28.6)\end{array}$ & $\begin{array}{c}0.41 \\
(0.25-0.55)\end{array}$ & $164 / 75$ & $\begin{array}{c}28.3 \\
(27.5-29.1)\end{array}$ & $\begin{array}{c}0.44 \\
(0.24-0.60)\end{array}$ \\
\hline 6-min walking test $(\mathrm{m})$ & - & - & - & - & - & - & - & - & - & $359 / 160$ & $\begin{array}{c}529.7 \\
(521.9-533.1)\end{array}$ & & $254 / 118$ & $\begin{array}{c}519.0 \\
(508.8-529.3)\end{array}$ & \\
\hline - MZ twins & - & - & - & - & - & - & - & - & - & $170 / 77$ & $\begin{array}{c}521.7 \\
(509.3-534.1)\end{array}$ & $\begin{array}{c}0.52 \\
(0.35-0.65)\end{array}$ & $120 / 57$ & $\begin{array}{c}524.0 \\
(508.0-540.0)\end{array}$ & $\begin{array}{c}0.66 \\
(0.48-0.78)\end{array}$ \\
\hline - DZ twins & - & - & - & - & - & - & - & - & - & 189/83 & $\begin{array}{c}528.7 \\
(519.3-538.1) \\
\end{array}$ & $\begin{array}{c}0.36 \\
(0.18-0.51)\end{array}$ & $134 / 61$ & $\begin{array}{c}514.5 \\
(501.2-527.8)\end{array}$ & $\begin{array}{c}0.36 \\
(0.13-0.56)\end{array}$ \\
\hline
\end{tabular}

* $\mathrm{N}$ expressed as number of individuals / complete twin pairs 
Table 2: BMI in middle age as an independent predictor of mobility in old age.

\begin{tabular}{c|ccc|ccc}
\hline & \multicolumn{3}{|c|}{ Mobility at 2001 } & \multicolumn{3}{c}{ Mobility at 2004 } \\
\hline PREDICTOR & $\mathbf{b}($ SE) & $\mathbf{P}$ & $\mathbf{R}^{2}$ & $\mathbf{b}$ (SE) & $\mathbf{P}$ & $\mathbf{R}^{2}$ \\
\hline BMI at 1975 & $-0.124(0.020)$ & $<0.001$ & 0.10 & $-0.124(0.021)$ & $<0.001$ & 0.10 \\
BMI at 1981 & $-0.122(0.019)$ & $<0.001$ & 0.10 & $-0.132(0.028)$ & $<0.001$ & 0.10 \\
BMI at 1990 & $-0.120(0.020)$ & $<0.001$ & 0.14 & $-0.117(0.028)$ & $<0.001$ & 0.12 \\
BMI at 2001 & $-0.100(0.015)$ & $<0.001$ & 0.12 & $-0.101(0.029)$ & $<0.001$ & 0.12 \\
BMI at 2004 & -- & -- & -- & $-0.093(0.020)$ & $<0.001$ & 0.10 \\
\hline BMI change & $-0.336(0.099)$ & $<0.001$ & 0.04 & $-0.359(0.124)$ & $<0.001$ & 0.04 \\
\hline
\end{tabular}

Note: results from age-adjusted linear regression modeling controlled for possible clusters of observations within twin pairs. $b$ (SE) refers to b coefficient and Standard Error. BMI change adjusted also for initial BMI value at year 1975 
Table 3. Fit statistics for longitudinal genetic growth models

\begin{tabular}{|c|c|c|c|c|c|c|c|}
\hline & \multirow[b]{2}{*}{$-2 \ln (L)$} & \multirow[b]{2}{*}{$d f$} & \multicolumn{5}{|c|}{ Fit relative to model 1} \\
\hline & & & $\Delta \chi^{2}$ & $\Delta d f$ & $P$ & $A I C$ & $B I C$ \\
\hline \multicolumn{8}{|l|}{ Growth Model for BMI and Mobility Level } \\
\hline 1. General model (AE parameterization) & -7489.192 & 2425 & -- & -- & -- & -- & -- \\
\hline 2. No As-BMI at each wave & -7483.192 & 2430 & 6.313 & 5 & 0.276 & -3.687 & -2.371 \\
\hline 2.1 No rg - Mobility Level and BMI Slope & -7478.572 & 2431 & 10.933 & 6 & 0.090 & -1.067 & -1.166 \\
\hline 2.2 No re - Mobility Level and BMI Slope & -7480.624 & 2431 & 8.881 & 6 & 0.180 & -3.119 & -2.192 \\
\hline 2.3 No relation between Mobility Level and BMI Slope & -7468.633 & 2432 & 20.872 & 7 & 0.003 & 6.872 & 2.698 \\
\hline 2.4 No As-Mobility at Wave 4 & -7482.214 & 2431 & 7.291 & 6 & 0.294 & -4.709 & -2.987 \\
\hline 2.5 No As-Mobility at Wave 5 & -7468.078 & 2431 & 21.426 & 6 & 0.002 & 9.427 & 3.289 \\
\hline 2.6 No As-Mobility at Wave 4, No rg - Mobility Level and BMI Slope & -7477.419 & 2432 & 12.086 & 7 & 0.097 & -1.964 & -1.694 \\
\hline 2.7 No As-Mobility at wave 4, No re - Mobility Level and BMI Slope & -7479.727 & 2432 & 9.778 & 7 & 0.201 & -4.212 & -2.844 \\
\hline 2.8 No As-Mobility at wave 4, No rg - Mobility Level and BMI Level & -7472.664 & 2432 & 16.841 & 7 & 0.018 & 2.841 & 0.681 \\
\hline 2.9 No As-Mobility at wave 4, No re - Mobility Level and BMI Level & -7473.431 & 2432 & 16.074 & 7 & 0.024 & 2.074 & 0.298 \\
\hline
\end{tabular}

Note: LL=Log-likelihood; $\mathrm{df}=$ degrees of freedom; $\Delta \chi^{2}=$ difference chi-squared between the model 1 and the fitted submodel, $\Delta \mathrm{df}=$ increment in degrees of freedom respecto the model 1 , AIC $=$ Akaike's Information Criterion, $\mathrm{BIC}=$ Bayesian Information Criterion. Lower values of AIC and BIC indicate better fit of the model to the data. The finally best-fitting model, with lowest AIC and BIC statistic, is shadowed. 
Figure 1: Summary model (lineal growth) for genetic and environmental influences on BMI over 29 year and its impact on Mobility level later in life

\section{Figure 1 here}

Note: Numbers represent percentage of variances (and 95\% Confidence Intervals) accounted for by additive genetic (A) and specific environmental (E) influences on BMI Level, BMI Slope and mobility Level. Estimates on curved arrows represent genetic and environmental correlations between BMI Level, BMI Slope and mobility Level. Es $\mathrm{x}_{\mathrm{x}}$ stands for percentages of variances accounted by specific environmental influences with no residual effects across occasions. $h^{2}$ represent standardized estimates of the overall genetic influence (or heritability) on BMI or mobility in every occasion. 




